\title{
PENDIDIK DALAM PERSPEKTIF PENDIDIKAN ISLAM
}

\author{
Oleh: \\ Besse Tantri Eka SB \& Muhammad Hasan Baidlawie \\ Besseeka31@gmail.com \\ BerkerHasan@gmail.com \\ Mahasiswa Magister UIN Sunan Kalijaga Yogyakarta
}

\begin{abstract}
ABSTRAK
Pendidik adalah orang yang sangat berperan dalam mencerdaskan anak bangsa, ketika bicara mengenai pendidik maka yang muncul dikepala kita adalah orang dewasa yang membimbing dan memberi kita sesuatu yang belum kita ketahui. Namun sungguh memprihatinkan nasib pendidik kita. Terlebih lagi jika kita melihat nasib pendidik di lembaga pendidikan swasta. Nasib pendidikan di Indonesia memang sungguh menyedihkan, kenyataan ini diperkuat dengan berita yang menyatakan bahwa Indonesia termasuk satu dari tujuh Negara yang dinilai oleh organisasi guru internasional yang tidak mempedulikan bidang pendidikan. Cermin ketidak pedulian itu terlihat dari rendahnya anggaran pendapatan dan belanja nasioanl (APBN) yang dialokasikan untuk pendidikan. Selain, itu, pemerintah Indonesia juga dinilai kurang memberikan perhatian pada kesejahteraan guru, di samping juga bahwa pendidikan di negeri ini juga masih dinilai diskriminatif.
\end{abstract}

Keyword : Pendidikan, Pendidikan Islam

\begin{abstract}
Educators are people who play a very important role in educating the children of the nation, when talking about educators then who appears in our heads are adults who guide and give us something we do not know. But it really concerns the fate of our educators. Moreover, if we look at the fate of educators in private educational institutions. The fate of education in Indonesia is indeed sad, this reality is reinforced by the news that states that Indonesia is one of seven countries assessed by international teacher organizations that do not care about the field of education. Such a reflection of ignorance is reflected in the low national budget (APBN) allocated to education. In addition, the Indonesian government is also considered to pay less attention to the welfare of teachers, as well as that education in this country is still considered discriminatory
\end{abstract}




\section{Pengertian Pendidik dalam Islam}

Dalam kamus Bahasa Indonesia dinyatakan, bahwa pendidik adalah orang yang mendidik. Dalam pengertian yang lazim digunakan, pendidik adalah orang dewasa yang bertanggung jawab memberikan pertolongan pada peserta didiknya dalam perkembangan jasmani dan rohaninya, agar mencapai tingkat kedewasaan, mampu berdiri sendiri dan memenuhi tingkat kedewasaanya, mampu mandiri dalam memenuhi tugasnya sebagai hamba dan khalifah Allah SWT, dan mampu melakukan tugas sebagai makhluk social dan sebagai makhluk individu yang mandiri. ${ }^{1}$

Sebagai kosa kata yang bersifat generik, pendidik mencakup pula guru, dosen, dan guru besar. Guru adalah pendidik profesional dengan tugas utama mendidik, mengajar, membimbing, mengarahkan, melatih, menilai dan mengevaluasi peserta didik pada pendidikan anak usia dini, jalur pendidikan formal, pendidikan dasar dan pendidikan menengah. Adapun dosen adalah pendidik professional dan ilmuwan dengan tugas utama mentransformasikan, mengembangkan dan menyebarluaskan ilmu pengetahuan, teknologi, dan seni melalui pendidikan, penelitian dan pengabdian kepada masyarakat. Guru besar atau profesor yang selanjutnya disebut profesor adalah jabatan fungsional tertinggi bagi dosen yang masih mengajar di lingkungan satuan pendidikan tinggi. ${ }^{2}$

Di dalam al-Qur'an dan as-Sunnah yang merupakan sumber utama ilmu pendidikan Islam, terdapat sejumlah istilah yang mengacu kepada pengertian pendidik. Istilah tersebut antara lain:

1. al-murabbi diartikan sebagai pendidik. Sebagaimana dijelaskan didalam Qs. Al-Isra': 24.

2. al-mu'allim diartikan sebagai pengajar, yakni memberi informasi tentang kebenaran dan ilmu pengetahuan. Sebagaimana dijelaskan didalam Qs. Albaqorah: 151 . hlm 159.

${ }^{1}$ Abuddin Nata, Ilmu Pendidikan Islam, (Jakarta: Kencana Prenada Media Group, 2010), 
3. al-muzakki diartikan sebagai orang yang melakukan pembinaan mental dan karakter yang mulia, dengan cara membersihkan si anak dari pengaruh akhlak yang buruk, terampil dalam mengendalikan hawa nafsu. Sebagaimana dijelaskan dalam Qs. Al-baqarah: 129.

4. al-ulama diartikan sebagai seorang peneliti yang menghasilkan berbagai temuan dalam bidang ilmu agama. Namun demikian, pengertian yang umum digunakan mengenai al-ulama ini yakni seseorang yang luas dan mendalami imu agama, memiliki karisma, akhlak mulia, dan kepribadian yang saleh.

5. al-faqih diartikan sebagai orang yang memiliki pengetahuan agama yang mendalam. Istilah ini lazim digunakan untuk orang-orang yang mendalami ilmu agama di berbagai pondok pesantren. Sebagaimana dijeaskan di dalam Qs. At-taubah: $122 .^{3}$

Adanya berbagai istilah sebagaimana tersebut diatas menunjukkan bahwa seorang pendidik dalam ajaran islam memiliki peran dan fungsi yang amat luas. Ketika berperan sebagai seorang orang yang menumbuhkan, membina, mengembangkan potensi anak didik serta membimbingnya, maka ia disebut almurabbi. Ketika berperan sebagai pemberi wawasan ilmu pengetahuan dan keterampilan, ia disebut sebagai al-muallim. Ketika ia membina mental dan karakter seseorang agar memiliki akhlak mulia, maka ia disebut al-muzakki. Ketika berperan sebagai peneliti yang berwawasan transendental serta memiliki kedalaman ilmu agama dan ketakwaan yang kuat kepada Allah, ia disebut alulama. Dan ketika berperan sebagai ahli agama, maka ia disebut al-faqih. ${ }^{4}$

Dalam pendidikan islam, pendidik adalah orang yang bertanggung jawab terhadap perkembangan peserta didik dengan upaya mengembangkan potensi peserta didik, baik potensi afektif (rasa), kognitif (cipta), maupun psikomotorik (karsa). Dalam paradigma jawa, pendidik diidentikkan dengan guru ( $g u$ dan $r u$ ) yang berarti "digugu" dan "ditiru”. Dikatakan digugu (dipercaya) karena guru memiliki seperangkat ilmu yang memadai, yang karenanya ia memiliki wawasan dan pandangan yang luas dalam melihat kehidupan ini. Dikatakan ditiru (diikuti)

\footnotetext{
${ }^{3}$ Ibid., hlm. 160-164.

${ }^{4}$ Ibid., hlm. 164-165
}

AL-IKHTIBAR (Jurnal Ilmu Pendidikan) Vol. 5 No. 2 Tahun 2018 
karena guru memiliki kepribadian yang utuh, yang karenanya segala tindak tanduknya patut dijadikan panutan dan suri teladan oleh peserta didik. Pengertian ini diasumsikan bahwa guru tidak sekedar mentransformasi ilmu, tetapi juga bagaimana ia mampu menginternalisasikan ilmunya kepada peserta didik. ${ }^{5}$

Berdasarkan uraian tersebut di atas, dapat penulis simpulkan, bahwa yang dimaksud dengan pendidik dalam islam ialah tenaga professional yang diserahi tugas dan tanggung jawab untuk menumbuhkan, membina, mengembangkan bakat, minat, kecerdasan, akhlak, moral, pengalaman, wawasan, dan keterampilan peserta didik. Seorang pendidik adalah orang yang berilmu pengetahuan dan berwawasan luas, memiliki keterampilan, pengalaman, berkepribadian mulia, memahami yang tersurat dan tersirat, menjadi contoh dan model bagi muridnya, senantiasa membaca dan meneliti, memiliki keahlian yang dapat diandalkan, serta menjadi penasihat dan memiliki pengetahuan agama yang luas.

\section{Kedudukan Pendidik dalam Islam}

Para ilmuan, mu'allim termasuk pendidik dalam islam menempati posisi yang sangat strategis, mulia, suci, terhormat dan tinggi. Nabi Adam as yang dibekali berbagai potensi dan diberi ilmu, maka ia dapat melaksanakan tugasnya sebagai khalifah dan hamba. Bahkan Allah menyuruh para malaikat dan iblis bersujud kepada Adam AS sebagai sujud ta'dzim (penghargaan/penghormatan) terhadap ilmunya Nabi Adam AS. Karena ilmu itu laksana cahaya, yang akan menerangi jalan hidup seseorang. Mengarungi kehidupan tanpa ilmu bagaikan orang berjalan di tengah malam yang gelap gulita, yang sewaktu-waktu terancam bahaya. “...Allah meninggikan derajat orang yang beriman dan berilmu”. (QS. Al-Mujadalah:11). Maka wajar kalau Imam Ghazali mengkhususkan penyebutan mu'allim dengan istilah kesucian dan keilmuan dan dia menempatkannya pada posisi setelah atau mengiringi para Nabi Allah itu. Sekiranya dunia ini kata Imam al-Ghazali, tidak ada pendidik, niscaya manusia seperti binatang, sebab pendidikan adalah upaya mengeluarkan manusia dari sifat kebinatangan menuju

${ }^{5}$ Abdul Mujib dan Jusuf Mudzakkir, Ilmu Pendidikan Islam, (Jakarta: Kencana Prenada Media Group, 2006), hlm 87.

AL-IKHTIBAR (Jurnal Ilmu Pendidikan) Vol. 5 No. 2 Tahun 2018 
kepada sifat insaniyah (kemanusiaan) dan ilahiyah (keberagaman). Harus di ingat pula bahwa posisi ilmuan dan pendidik itu tinggi jika disertai dengan iman-takwa. Seorang ilmuwan yang tidak tidak beriman takwa, akan dapat menghancurkan dirinya dan orang lain, karena jiwanya tidak dikontrol oleh nilai-nilai spiritual. Tentang penghargaan terhadap ilmu pengetahuan termasuk pemiliknya (ilmuan) ialah (1). Tinta ulama termasuk pendidik, lebih berharga dari pada darah syuhada dan (2). ilmuan melebihi orang yang senang beribadah, yang berpuasa dan menghabiskan waktu malamnya untuk mengerjakan shalat, bahkan melebihi seorang yang berjihad di jalan Allah. ${ }^{6}$

Pendidik adalah bapak ruhani (spiritual father) bagi peserta didik, bagi peserta didik yang membarikan santapan jiwa dengan ilmu, pembinaan akhlak dan meluruskan perilaku yang buruk. Oleh karena itu, pendidik mempunyai kedudukan tinggi di dalam Islam. Dalam beberapa hadits disebutkan: "Jadilah engkau sebagai guru, atau pelajar, atau pendengar atau pencinta dan janganlah kamu menjadi orang yang kelima, sehingga kamu menjadi rusak". 7

Dapat disimpulkan bahwa kedudukan pendidik dalam Islam itu sangatlah mulia sesuai dengan tugas dan perannya yang sangat berat, bahwa pendidik itu adalah pencerdas bangsa pembangun agama, oleh karenanya jika baik pendidiknya maka akan baik pula bangsa dan agama namun jika buruk pendidiknya maka akan buruk pula bangsa dan agama kita.

\section{Syarat-Syarat Pendidik dalam Islam}

Berikut ini adalah gambaran bagaimana para ahli pendidik musli memberikan syarat-syarat pendidik yang super ketat, terutama persyaratan yang berkaitan dengan personal atau kepribadian. Menurut Imam al-Ghazali (Muhammad Jawad Rida, 1980 dan Fathiyah Hasan Sulaiman, 1964) seorang pendidik harus memiliki delapan sifat-sifat khusus atau tugas-tugas tertentu yaitu:

\footnotetext{
${ }^{6}$ Maragustam Siregar, Filsafat Pendidikan Islam,(Yogjakarta: Kurnia Kalam Semesta, 2016), hlm 206-207.

${ }^{7}$ Bukhari Umar, Ilmu Pendidikan Islam, (Batusangkar: Amzah, 2010), hlm. 86-87

AL-IKHTIBAR (Jurnal Ilmu Pendidikan) Vol. 5 No. 2 Tahun 2018
} 
a. Guru memiliki rasa sayang, karena dengan sifat ini, maka akan timnul rasa percaya diri dan rasa tenteram pada diri peserta didik terhadap gurunya. Hal ini sangat membantu peserta didik dalam menguasai ilmu.

b. Guru tidak boleh menuntut upah atas jerih payahnya dalam mengajar da mengharap pujian, ucapan terima kasih atau balasan bagi peserta didiknya, karena mengajar itu wajib bagi setiap orang yang berilmu.

c. Guru bertindak sebagai petugas penyuluh yang jujur dan benar dihadapan peserta didiknya, ia tidak boleh membiarkan peserta didiknya mempelajari materi yang lebih tinggi sebelum ia menguasai pelajaran sebelumnya.

d. Guru tidak menggunakan kekerasan, mencemooh dalam membina mental dan perilaku peserta didiknya, tetapi dengan cara penuh simpatik dan kasih saying.

e. Mengingat guru sebagai teladan, maka kebaikan hati dan toleran haruslah dimilikinya. Seperti menghargai terhadap ilmu lain yang bukan spesialisasinya, tidak menjelekkan dan merendahkan nilainya.

f. Guru menjaga prinsip penjagaan perbedaan-perbedaan antar individu, yang menuntut diadakannya perbedaan antara masing-masing peserta didik berdasarkan kemampuan akal atau kemampuan-kemampuan lainnya. Guru membatasi dirinya dalam mengajar pada batas kemampuan pemahaman peserta didik, dan karenanya ia tidak perlu memberikan sesuatu yang tak terjangkau oleh akalnya, karena dapat menimbulkan rasa antipasti atau merusak akalnya.

g. Guru mempelajari kejiwaan peserta didik, sehingga ia tahu bagaimana seharusnya ia memperlakukannya sehingga ia terjauh dari rasa ragu-ragu dan gelisah. Untuk itu Imam al-Ghazali menganjurkan agar guru hanya memberi ilmu-ilmu yang jelas dan tidak rumit, sekalipun guru menguasainya kepada peserta didik yang kurang mampu akalnya. Karena kalau guru memberikan ilmu yang rumit kepada pembelajar yang kurang cerdas, akan menurunkan semangatnya dan dapat membingungkannya, atau timbul prasangka bahwa guru tak mau memberikan ilmu kepadanya.

h. Guru mau mengamalkan ilmunya, sehingga yang ada adalah menyatunya perbuatan yang bagi peserta didiknya hal itu tidak boleh, sebab jika tidak 
demikian, maka guru akan kehilangan wibawa, yang pada gilirannya akan kehilangan kemampuan dalam mengatur peserta didiknya ${ }^{8}$.

Menurut al-Abrasyi, syarat menjadi guru itu ialah zuhud (tidak terlalu suka kepada kehidupan dunia, hidup sederhana), suci, ikhlas dalam bekerja, lemah lembut, tenang, sopan dan suka pemaaf, menjadi bapak sebelum ia menjadi guru, mengerti tabiat, kecenderungan, kebiasaan, perasaan dan pikiran peserta didiknya agar tidak salah arah dalam peserta didikan, bersih fisik dan jiwa dari dosa besar dan kesalahan, jauh dari sifat mencari nama, dengki, permusuhan dan sifat-sifat tercela lainnya, tetap menekuni dan membahas mata pelajaran yang terjadi tugasnya, sehingga materi pengajaran tidak menjadi kering. ${ }^{9}$

\section{Peran dan Tugas Pendidik dalam Islam}

Dalam pandangan islam, guru yaitu subjek yang melaksanakan pendidikan islam, dan guru ini juga mempunyai peran penting terhadap berlangsungnya pendidikan. Oleh karena itu, baik buruknya guru berpengaruh besar terhadap hasil pendidikan islam dikemudian hari. Guru juga merupakan sebuah public figure yang akan dijadikan panutan pelajarnya, maka guru harus memiliki akhak yang luhur. Pembinaan dan pembimbingan murid dari guru yang berakhlak luhur sangat menentukan terbentuknya perilaku sebagai pencerminan dari akhlakul karimah. Dalam Undang-undang sistem pendidikan Nasional pasal 27 ayat 3, ada tiga peranan guru. 1. Sebagai pengajar, 2. Sebagai pembimbing dan 3. Sebagai administrator kelas.

Menurut Al-Ghazali, tugas pendidik yang utama adalah menyempurnakan, membersihkan, menyucikan serta membimbing hati manusia untuk mendekatkan diri kepada Allah SWT. Hal tersebut karena tujuan pendidikan islam yang utama adalah upaya untuk mendekatkan diri kepada-Nya. Jika pendidik belum mampu membiasakan diri dalam peribadatan kepada peserta didik, berarti ia mengalami kegagalan di dalam tugasnya, sekalipun peserta didik memiliki prestasi akademis

\footnotetext{
${ }^{8}$ Siregar, Filsafat Pendidikan Islam...,hlm. 207-209.

${ }^{9}$ Ibid., hlm. 209.
}

AL-IKHTIBAR (Jurnal Ilmu Pendidikan) Vol. 5 No. 2 Tahun 2018 
yang luar biasa. Hal tersebut mengandung arti akan keterkaitan antara ilmu dan amal shaleh ${ }^{10}$.

Dan pendapat yang lain juga mengatakan, tugas pendidik adalah mendidik dengan mengupayakan pengembangan seluruh potensi peserta didik, baik aspek kognitif, efektif, maupun psikomotoriknya. Potensi peserta didik ini harus berkembang secara seimbang sampai ke tingkat keilmuan tertinggi dan mengintegrasi dalam diri peserta didik. Upaya pengembangan potensi anak didik tersebut dilakukan untuk penyucian jiwa-mental, penguatan metode berfikir, penyelesaian masalah kehidupan, mentransfer pengetahuan dan keterampilannya melalui tehnik mengajar, memotivasi, memberi contoh, memuji, dan mentradisikan keilmuan. ${ }^{11}$

Terkadang seseorang terjebak dengan sebutan pendidik, misalnya ada sebagian orang yang mampu memberikan dan memindahkan ilmu pengetahuan (transfer the knowlegde) kepada orang lain sudah dikatakan sebagai pendidik. Sesungguhnya seorang pendidik bukan hanya menjalankan tugas tersebut, tetapi pendidik juga bertanggung jawab atas pengelolaan (manager of learning), pengarah (director of learning), fasilitator, dan perencana (the planner of future society). Oleh karena itu, fungsi dan tugas pendidik dalam pendidikan dapat disimpulkan menjadi tiga bagian, yaitu sebagai berikut:

1. Sebagai pengajar (intruksional) yang bertugas merencanakan program pengajaran dan melaksanakan program yang telah disusun serta melaksanakan penilaian setelah program dilakukan.

2. Sebagai pendidik (aducator) yang mengarahkan peserta didik pada tingkat kedewasaan dan kepribadian kamil seiring dengan tujuan Allah SWT menciptakannya.

3. Sebagai pemimpin (managerial) yang memimpin, mengendalikan diri sendiri, peserta didik dan masyarakat yang terkait terhadap berbagai masalah yang

\footnotetext{
${ }^{10}$ Umar, Ilmu Pendidikan Islam..., hlm 87.

${ }^{11}$ Moh. Roqib, Ilmu Pendidikan Islam, (Yogyakarta: PT LKIS Sprinting, 2008), hlm 50-
} 
menyangkut upaya pengarahan, pengawas, perorganisasian, pengontrolan dan partisipasi atas program pendidikan yang dilakukan. ${ }^{12}$

Namun dari sumber yang lain dikatakan tugas pendidik dalam proses pembelajaran secara berurutan adalah:

1. Menguasai materi pembelajaran

2. Menggunakan metode pembelajaran agar peserta didik mudah menerima dan memahami pelajaran

3. Melakukan evaluasi pendidikan yang dilakukan

4. Menindak lanjuti hasil evaluasinya. Tugas seperti ini secara keilmuan mengharuskan pendidik menguasai ilmu-ilmu bantu yang dibutuhkan, seperti ilmu pendidikan, psikologi pendidikan/pembelajaran, media pembelajan, media pembelajaran, evaluasi pendidikan dan lainnya.

Oleh karena itu, dapat penulis simpulkan bahwa peran pendidik atau guru agama islam tidak hanya sebagai pengajar saja yang hanya memberikan dan menyampaikan materi ketika berada didalam kelas. Atau hanya menjadi pembimbing saja, yang mana pendidik hanya berperan sebagai penunjuk arah atau sekedar memberitahu peserta didiknya akan nilai-nilai moral yang baik, bukan hanya itu , tapi peran pendidik itu mencakup dalam segala aspek, bahwa guru itu berperan sebagai pengajar, dan guru juga berperan sebagai pembimbing dan juga berperan sebagai administrator kelas.

Oleh karenanya kita harus mengetahui bahwa peran guru itu sangat penting dalam sistem pendidikan dan pembelajaran, karena guru, tidak hanya sekedar mengajar memberikan materi di dalam kelas setelah itu pulang, bukan hanya itu, tapi guru juga sebagai motivator, penasihat dan sebagai orang tua kedua peserta didiknya ketika disekolah, oleh karenanya guru harus bisa benar-benar membina dan membimbing peserta didiknya, selain itu guru juga mempunyai peran sebagai administrator kelas, dalam arti guru dapat menjadi penengah ketika terjadinya perbedaan pendapat di dalam kelas, selain itu juga guru sebagai fasilitator, artinya guru atau pendidik harus menyiapkan segala sesuatu yang bersangkut paut mengenai persiapan pembelajaran, misal rencana pelaksanaan

${ }^{12}$ Umar, Ilmu Pendidikan Islam...,hlm. 88-89

AL-IKHTIBAR (Jurnal Ilmu Pendidikan) Vol. 5 No. 2 Tahun 2018 
pembelajaran (RPP), media yang digunakan, metode, dan lain sebagainya yang dapat menjadi pendukung dalam proses belajar mengajar berlangsung.

\section{Kompetensi Pendidik}

Pendidik dalam menjalankan tugasnya dituntut memiliki beberapa kompetensi guna menunjang kesuksesan tugas-tugasnya. Kompetensi yang dimiliki dapat berupa kompetensi keilmuan, fisik, social dan juga etika-moral. Diantara sekian banyak tugas dan kompetensi yang harus dimiliki oleh pendidik, diantara adalah:

1. Mengajarkan sesuai dengan kemampuan (bidang keilmuan)-nya, dalam arti pendidik harus memahami dan menguasai ilmu yang diajarkan serta peta konsep dan fungsinya agar tidak menyesatkan dan harus selalu belajar untuk mendalami ilmu.

2. Berperilaku rabbani, takwa dan taat kepada Allah.

3. Memiliki integritas moral sebagaimana rasul bersifat shidiq (jujur), amanah (memegang tugas dengan baik), tabligh (selalu menyampaikan informasi dengan kebenaran), dan fathanah (cerdas dalam bersikap).

4. Mencintai dan bangga terhadap tugas-tugas keguruan dan melaksanakan dengan penuh gembira, kasih saying, tenan dan sabar.

5. Memiliki perhatian yang cukup dan adil individualitas dan kolektivitas peserta didik.

6. Sehat rohani, dewasa menjaga kemuliaan diri (wara'), humanis, bewibawa dan penuh keteladanan.

7. Menjalin komunikasi yang harmonis dan rasional dengan peserta didik dan masyarakat.

8. Menguasai perencanaan, metode dan strategi mengajar dan juga mampu melakukan pengelolaan kelas dengan baik.

9. Menguasai perkembangan fisikk dan psikis peserta didik serta menghormatinya. 
10. Eksploratif, apresiatif, responsif, dan inovatif terhadap perkembangan zaman, seperti perkembangan ilmu pengetahuan dan teknologi, terutama dalam bidang komunikasi dan informasi.

11. Menekankann pendekatan student centered, learning by doing, dan kontekstual-integral.

12. Melakukan promosi wacana dan pembentukan watak dan keilmuan yang otonom $^{13}$.

Tanggung jawab profesional pendidik (professional responsibilities) diartikan sebagai (a).bertanggung jawab secara khusus untuk selalu menambah dan memperbarui (updating) pengetahuan, (b).mencari cara-cara baru untuk meningkatkan efektivitas-aktivis intruksional dan educative, (c).mengembangkan bidang keilmuan yang diampui melalui riset dan kajian ilmiah, (d). Mengembangkan kolegialitas melalui kontribusi untuk pengembangan kurikulum (e) memainkan peran aktif dalam melindungi dan meningkatkan professional and academic standing.

Dalam bahasa Undang-Undang Guru dan Dosen, kompetensi guru dikatagorikan menjadi empat: pertama, kompetensi pedagogik dalam arti guru harus paham terhadap peserta didik, perancangan, pelaksanaaan dengan memahmi semua aspek potensi peserta didik, menguasai teori dan strategi belajar serta pembelajarannya, mampu merancang pembelajaran, menata latar dan melaksanakannya dan mampu melakukan pengembangan akademik dan non akademik

Kedua, kompetensi kepribadian, dalam arti guru harus memiliki kepribadian yang mantap dan stabil, dewasa, arif, berwibawa dan berakhlak mulia dengan melaksanakan norma hukum dan social memiliki rasa bangga dengan profesi guru, konsisten dengan norma, mandiri, memiliki etos kerja tinggi, meiliki pengaruh positif, diteladani dan segani melaksanakan norma relius serta jujur.

Ketiga, kompetensi professional, dalam arti guru harus menguasai keilmuan bidang studi yang diajarkannya, serta mampu melakukan kajian kritis dan pendalaman isi bidang studi.

${ }^{13}$ Ibid.,hlm.51-52

AL-IKHTIBAR (Jurnal Ilmu Pendidikan) Vol. 5 No. 2 Tahun 2018 
Keempat, kompetensi social, dalam arti guru harus mampu berkomunikasi dan bergaul dengan peserta didik, kolega, dan masyarakat yakni dengan kemampuan bersikap menarik, empati, kolaboratif, suka menolong, menjadi panutan, komunikatif dan kooperatif ${ }^{14}$.

Ada juga sumber lain yang mengatakan bahwa guru membawa amanah ilahiah untuk mencerdaskan kehidupan umat manusia dan mengarahkannya untuk senantiasa taat beribadah kepada Allah dan berakhlak mulia. Oleh karena tanggung jawabnya, guru dituntut untuk memiliki kompetensi profesional, pedagogik, social, kepribadiaan dan kepemimpinan. Kompetensi adalah seperangkat pengetahuan, keterampilan, dan perilaku yang harus dimiliki, dihayati dan dikuasai oleh guru dan melaksanakan tugas profesionalannya. Oleh karena itu, akan dijelaskan beberapa kompetensi yakni:

\section{Kompetensi Profesional}

Kompetensi professional adalah kemampuan penguasaan materi pembelajaran secara luas dan mendalam yang memungkinkan membimbing peserta didik memenuhi standar kompetensi yang ditetapkan dalam standar nasional pendidikan. Di dalam islam, seorang pendidik dituntut agar bersifat professional sebab jika guru tersebut tidak professional, tujuan pendidikan tidak dapat dicapai. Didalam Qs. Al-An'am: 135

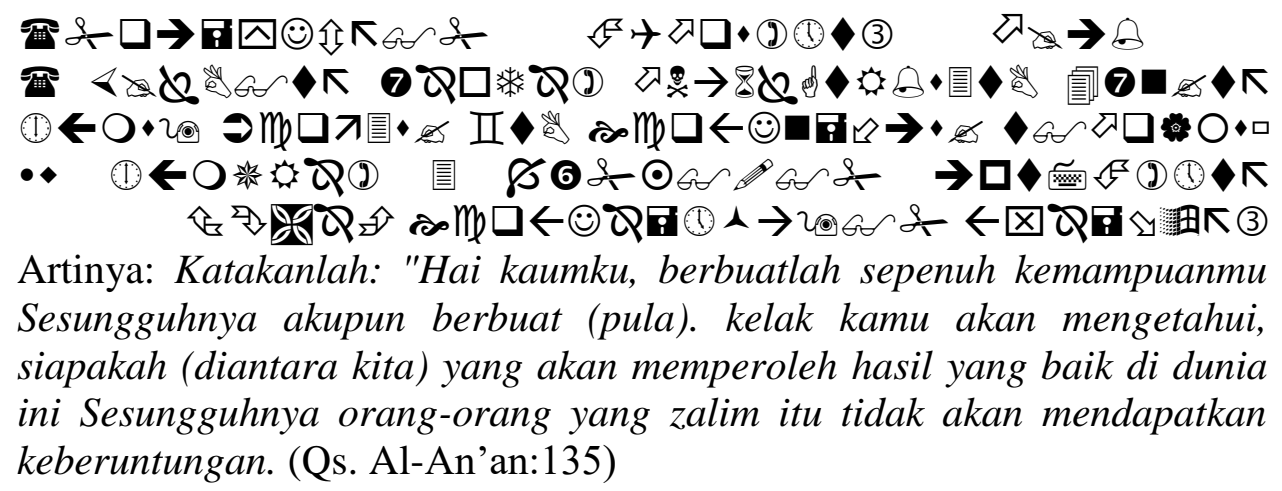

dan didalam hadits juga dijelaskan yang artinya:

$$
\text { إِذَا وُسِدَ الأَهْرُ إلىى غَيْرِ أَهْلِهِهِ فَانْتَظِرِ السَّاعَةَ }
$$

${ }^{14}$ Ibid.,hlm. 52-53

AL-IKHTIBAR (Jurnal Ilmu Pendidikan) Vol. 5 No. 2 Tahun 2018 
Artinya: "Apabila suatu pekerjaan diserahkan tepat kepada orang yang bukan ahlinya, maka tunggulah kehancurannya." (HR. Muslim) ${ }^{15}$.

2. Kompetensi pedagogik

Kompetensi pedagogik merupakan kemampuan guru dalam mengelola pembelajaran peserta didik yang sekurang-kurangnya meliputi:

a. Memahami wawasan atau landasan kependidikan

b. Pemahaman terhadap peserta didik

c. Pengembangan kurikulum dan silabus

d. Perancangan pembelajaran

e. Pelaksanaan pembelajaran yang mendidik dan dialogis.

f. Pemanfaatan teknologi pembelajaran

g. Pengembangan peserta didik untuk mengaktualisasikan berbagai potensi yang dimilikinya ${ }^{16}$.

\section{Kompetensi Sosial}

Kompetensi sosial ialah kemamapuan pendidik sebagai bagian dari masyarakat untuk berkomunikasi dan bergaul secara efektif dan efisien dengan peserta didik, tenaga kependidikan, wali peserta didik dan masyarakat. kompetensi ini sekurang-kurangnya meliputi hal-hal berikut:

a. Berkomunikasi secara lisan, tulisan dan isyarat

b. Menggunakan teknologi informasi komunikasi secara fungsional

c. Bergaul secara efektif dan efisien dengan peserta didik, sesama pendidik, tenaga kependidikan, pimpinan satuan pendidikan, wali peserta didik dan masyarakat

d. Bergaul secara santuan dengan masyarakat sekitar dengan mengindahkan norma serta sistem nilai yang berlaku.

e. Menerapkan prinsip-prinsip persaudaraan sejati dan semangat kebersamaan. ${ }^{17}$

${ }^{15}$ Novan Ardy Wiyani dan Barnawi, Ilmu Pendidikan Islam, (Yogyakarta: Ar-Ruzz Media, 2012), hlm 102.

${ }^{16}$ Ibid., hlm. 103

${ }^{17}$ Ibid., 103

AL-IKHTIBAR (Jurnal Ilmu Pendidikan) Vol. 5 No. 2 Tahun 2018 


\section{Kompetensi Kepribadian}

Kompetensi kepribadian adalah kepribadian yang mantap, stabil, dewasa, arif, berwibawa dan berakhlak mulia serta menjadi teladan bagi peserta didik. Tanpa mengabaikan kompetensi yang lainnya, menurut Zakiyah Daradjat, kompetensi sosial dan kepribadian merupakan kompetensi yang terpenting. Dalam hal ini, ada korelasi yang erat antara kompetensi sosial dan kompetensi kepribadian. Dari kompetensi kepribadian guru dapat dievaluasi apakah ia seorang guru yang baik atau tidak. Kepribadian yang utuh meliputi tingkah laku maupun tata bahasanya. Sebab kepribadian guru akan mudah diperhatikan dan ditiru oleh peserta didiknya, termasuk budi. Oleh karena itu, menurut Imam Zarnuji, guru seharusnya adalah seorang yang alim, wara' dan lebih tua (dewasa). Persyaratan ini penting dipenuhi oleh guru sebab guru menjadi symbol personifikasi bagi subjek didiknya. Lebih lanjut, Athiyah-al-Abrasyi memberikan syarat kepribadian seorang pendidik sebagai berikut:

a. Zuhud dan ikhlas

b. Bersih latir dan batin

c. Pemaaf, sabar dan mampu mengendalikan diri

d. Bersifat kebapakan dan keibuan (dewasa)

e. Mengenal dan memahami peserta didik dengan baik

Guru yang baik tetap berproses untuk meningkatkan kualitas ilmu, strategi pembelajaran, maupun kepribadiannya. Guru yang merasa sudah baik berarti ia bukan guru yang baik karena hal tersebut merupakan pertanda bahwa ia enggan menjadi lebih baik. Guru yang ideal adalah guru yang pada saat bersamaan siap menjadi peserta didik.

Adapun peraturan Menteri Agama Republik Indonesia Nomor 16 Tahun 2010 tentang Pengelolaan Pendidikan Agama pada sekolah bahwa guru pendidikan agama harus memiliki kompetensi pedagogic, kepribadiaan, sosial, profesional, dan kepemimpinan.

1. Kompetensi pedagogic sebagaimana yang dimaksud, meliputi:

a. Pemahaman karakteristik peserta didik dari aspek fisik, moral, sosial, kultural, emosional dan intelektual. 
b. Penguasaan teori dan prinsip belajar pendidikan agama

c. Pengembangan kurikulum pendidikan agama

d. Penyelenggaraan kegiatan pengembangan pendidikan agama

e. Pemanfaatan teknologi informasi dan komunikasi untuk kepentingan penyelenggaraan dan pengembangan pendidikan agama

f. Pengembangan potensi peserta didik untuk mengaktualisasikan berbagai potensi yang dimiliki dalam bidang pendidikan agama

g. Komunikasi secara afektif, empatik, dan santun dengan peserta didik

h. Penyelenggaraan penilaiaan dan evaluasi proses dan hasil belajar pendidikan agama

i. Pemanfaatan hasil penilaian dan evaluasi umtuk kepentingan pembelajaran pendididikan agama, dan

j. Tindakan reflektif untuk peningkatan kualitas pembelajaran pendidikan agama. ${ }^{18}$

2. Kompetensi kepribadiaan sebagaimana yang dimaksud, meliputi:

a. Tindakan yang sesuai dengan norma agama, hukum, sosial dan kebudayaan nasional Indonesia.

b. Penampilan diri sebagai pribadi yang jujur, berahlak mulia, dan teladan bagi peserta didik dan masyarakat.

c. Penampilan diri sebagai pribadi yang mantap, stabil, dewasa, arif dan berwibawa.

d. Memiliki etos kerja, tanggung jawab yang tinggi, rasa bangga menjadi guru dan rasa percaya diri, serta

e. Penghormatan terhadap kode etik profesi guru. ${ }^{19}$

${ }^{18}$ Peraturan Menteri Agama Republik Indonesia Nomor 16 Tahun 2010, Tentang Pengelolaan Pendidikan Agama pada Sekolah.

${ }^{19}$ Ibid., hlm 10

AL-IKHTIBAR (Jurnal Ilmu Pendidikan) Vol. 5 No. 2 Tahun 2018 
3. Kompetensi sosial sebagaimana yang dimaksud, meliputi:

a. Sikap inklusif, bertindak objektif, serta tidak diskriminatif berdasarkan jenis kelamin, agama, ras, kondisi fisik, latar belakang keluarga, dan status sosial ekonomi.

b. Sikap adaptif dengan lingkungan sosial budaya tempat bertugas, dan

c. Sikap komunikatif dengan komunitas guru, warga sekolah dan warga masyarakat. ${ }^{20}$

4. Kompetensi Profesional sebagaimana yang dimaksud, meliputi:

a. Penguasaan materi, struktur, konsep dan pola piker keilmuan yang mendukung mata pelajaran pendidikan agama

b. Penguasaan standar kompetensi dan kompetensi dasar mata pelajaran pendidikan agama

c. Pengembangan materi pembelajaran mata pelajaran pendidikan agama secara kreatif

d. Pengembangan profesionalitas secara berkelaanjutan dengan melakukan tindakan reflektif, dan

e. Pemanfaatan teknologi informasi dan komunikasi untuk berkomunikasi dan mengembangkan diri. ${ }^{21}$

5. Kompetensi kepemimpinan sebagaimana yang dimaksud, melipui:

a. Kemampuan membuat perencanaan pembudayaan pengamalan ajaran agama dan perilaku akhlak mulia pada komunitas sekolah sebagai bagian dari proses pembelajaran agama

b. Kemampuan mengorganisasikan potensi unsur sekolah secara sistematis untuk mendukung pembudayaan pengamalan ajaran agama pada komunitas sekolah

c. Kemampuan menjadi innovator, motivator, fasilitator, pembimbing dan konselor dalam pembudayaan pengamalan ajaran agama pada komunitas sekolah.

${ }^{20}$ Ibid., hlm 10

${ }^{21}$ Ibid., hlm 10.

AL-IKHTIBAR (Jurnal Ilmu Pendidikan) Vol. 5 No. 2 Tahun 2018 


\section{KESIMPULAN}

Pendidik dalam sudut pandang islam adalah orang yang memberi informasi tentang pembenaran ilmu pengetahuan atau orang yang melakukan pembinaan mental dan karakter yang mulia, atau peneliti yang menghasilkan temuan dalam bidang agama dan bisa disebut juga orang yang memiliki pengetahuan agama yang luas. Sehingga kedudukan seorang pendidik dalam islam sangat dimuliakan oleh Allah SWT, sebagaimana yang telah banyak disinggung di dalam Al-Qur'an dan As-Sunah.

Begitu pula dengan peran dan tugas pendidik yang sangat banyak, seorang pendidik harus mampu menjadi public figure bagi peserta didiknya, harus mampu mengawasi, membina dan juga membimbing sehingga peserta didik dapat mengambil nilai-nilai moral yang positif dari pendidik tersebut. Juga seorang pendidik harus memiliki kompetensi yang mampuni guna untuk menunjang kesuksesan dalam proses belajar mengajar. Sehingga seorang pendidik harus dapat memiliki beberapa potensi yang sudah ditetapkan didalam Undang-Undang guru dan dosen diantaranya kompetensi paedagogik, kompetensi kepribadian, kompetensi kepribadian dan kompetensi sosial. Ini lah beberapa kompetensi yang harus dimiliki oleh pendidik yang profesional.

\section{DAFTAR PUSTAKA}

Barnawi, Ardy wiyani Novan, Ilmu Pendidikan Islam, Yogjakarta: Ar-Rozz Media, 2012.

Mujib Abdul, Mudzakkir Jusuf, Ilmu Pendidikan Islam, Jakarta: Kencana Prenada Media Group, 2016.

Nata, Abudin, Ilmu Pendidikan Islam, Jakarta: Kencana Prenada Media Group, 2010 .

Peraturan Menteri Agama Republik Indonesia Nomor 16 Tahun 2010, Tentang Pengelolaan Pendidikan Agama pada Sekolah.

Roqib, M, Iimu Pendidikan Islam, Yogyakarta: PT. LKIS Sprinting, 2008.

Umar, Bukhori, Ilmu Pendidikan Islam, Batu Sangkar: Amzah, 2010.

Siregar, Maragustam, Filsafat Pendidikan Islam, Yogyakarta: Kurnia Kalam Semesta, 2016. 
